\title{
Terapi pada Pasien Kanker Payudara Stadium Lanjut Menurunkan Kadar C- Reaktif Protein dan Meningkatkan Kadar Albumin
}

\author{
${ }^{1}$ Arya Wawolumaja, ${ }^{2}$ Victor Pontoh, ${ }^{2}$ Marselus Merung \\ ${ }^{1}$ PPDS Ilmu Bedah Umum Fakultas Kedokteran Universitas Sam Ratulangi Manado \\ ${ }^{2}$ Divisi Bedah Onkologi Bagian Ilmu Bedah Universitas Sam Ratulangi/RSUP Prof. Dr. R. \\ D. Kandou Manado \\ Email: arya_doctor@yahoo.com
}

\begin{abstract}
Breast cancer is one of the malignancies that has a high prevalence and can occur in both sexes. Albeit, more than $70 \%$ of these patients were detected at late stage. Inflammation could accelerate the tumor growth, invasion, angiogenesis, and metastasis. Increased serum CRP indicates uncontrolled infection or pathological process. Meanwhile, serum albumin is used to evaluate the nutrition status, the severity of disease, and prognosis. This study was aimed to evaluate the influence of serum CRP and albumin levels in female patients with breast cancer after treatment. This was an interventional analytical study with a cross sectional design. This study was conducted at Prof. Dr. R. D. Kandou Hosppital Manado. Subjects were all female patients with breast cancer from May to August 2018. The results showed that there were 43 patients of late stage breast cancer, mean age of 52.16 years. After treatment there was a decrease in the mean serum CRP level from $17.05 \mathrm{mg} / \mathrm{dL}$ to $6.40 \mathrm{mg} / \mathrm{dL}$ and the paired $\mathrm{t}$ test obtained a t value of 3.269 and a $P$ value of 0.001 . Moreover, there was an increase in the mean serum albumin level from $3.59 \mathrm{mg} / \mathrm{L}$ to $3.76 \mathrm{mg} / \mathrm{L}$ and the paired t test obtained a $\mathrm{t}$ value of $-2,896$ and a $P$ value of $=0.003$. Conclusion: Chemotherapy and or surgery performed on female patients with breast cancer could decrease the serum CRP level and increase the serum albumin level.
\end{abstract}

Keywords: breast cancer, serum CRP, serum albumin

\begin{abstract}
Abstrak: Kanker payudara merupakan salah satu jenis keganasan yang memiliki prevalensi cukup tinggi dan dapat terjadi baik pada laki-laki maupun perempuan. Lebih dari $70 \%$ penderita kanker payudara ditemukan pada stadium lanjut. Keadaan inflamasi dapat mempercepat pertumbuhan tumor, invasi, angiogenesis, dan metastasis. Hadirnya CRP serum yang meningkat mengindikasikan adanya infeksi atau proses patologik yang tidak teratasi. Albumin serum secara umum digunakan untuk menilai status nutrisi, derajat keparahan penyakit, perkembangan penyakit, dan prognosisnya. Penelitian ini bertujuan untuk menilai pengaruh kadar CRP dan albumin serum pada pasien perempuan dengan kanker payudara stadium lanjut setelah terapi. Jenis penelitian ialah intervensional analitik dengan desain potong lintang Penelitian dilakukan di RSUP Prof. Dr. R. D. Kandou Manado. Subjek penelitian ini ialah semua penderita kanker payudara berjenis kelamin perempuan pada periode Mei 2018 s/d Agustus 2018. Hasil penelitian mendapatkan 43 pasien dengan kanker payudara stadium lanjut dengan usia rerata 52,16 tahun. Setelah terapi terjadi penurunan rerata kadar CRP serum dari $17,05 \mathrm{mg} / \mathrm{dL}$ menjadi $6,40 \mathrm{mg} / \mathrm{dL}$ dan uji t berpasangan menunjukkan nilai $\mathrm{t}=3,269$ dengan $P=0,001$. Selain itu, terjadi peningkatan rerata kadar albumin serum dari $3,59 \mathrm{mg} / \mathrm{L}$ menjadi $3,76 \mathrm{mg} / \mathrm{L}$ dan uji $\mathrm{t}$ berpasangan menunjukkan nilai $\mathrm{t}=-2,896$ dengan $P=0,003$. Simpulan: Modalitas kemoterapi dan/atau operasi pada pasien kanker payudara stadium lanjut secara bermankna menurunkan kadar CRP serum tetapi meningkatkan kadar albumin serum.
\end{abstract}

Kata kunci: kanker payudara, CRP serum, albumin serum 
Kanker payudara merupakan salah satu jenis keganasan yang memiliki prevalensi cukup tinggi dan dapat terjadi pada lakilaki maupun perempuan, dengan prevalensi yang jauh lebih tinggi pada perempuan. Pada tahun 2017, di Amerika Serikat terdapat 252.710 kasus baru pada perempuan dan 2.470 kasus baru pada laki-laki, dengan 40.610 kasus kematian pada perempuan dan 460 kasus kematian pada laki-laki. ${ }^{1}$ Kanker payudara merupakan keganasan dengan jumlah terbanyak di Indonesia, khususnya pada perempuan (17,77$19,52 \%)$. Selain jumlah kasusnya yang tinggi, lebih dari $70 \%$ penderita kanker payudara ditemukan pada stadium lanjut. Hal tersebut yang menyebabkan tingginya angka kematian pada jenis keganasan ini. ${ }^{2}$ Kanker payudara merupakan salah satu penyebab utama kematian pada perempuan di seluruh dunia. Tingkat ketahanan hidup 5 tahun mendekati 97\% ketika sel-sel tumor terbatas pada jaringan payudara, dan akan menurun secara dramatis menjadi $23 \%$ ketika sel-sel tumor telah bermetastasis ke organ-organ lain pada saat diagnosis. ${ }^{3}$

Telah diketahui bahwa variasi hasil luaran penderita karsinoma tidak hanya semata ditentukan dari karakteristik tumor tetapi juga faktor respons tubuh. Keadaan inflamasi dapat mempercepat pertumbuhan tumor, invasi, angiogenesis, dan bahkan metastasis. Peningkatan petanda peradangan (protein reaktif $\mathrm{C}$ ) berhubungan dengan menurunnya ketahanan hidup penderita pada perempuan. ${ }^{4}$

Protein reaktif $\mathrm{C}(\mathrm{CRP})$ merupakan petanda yang menggambarkan kondisi peradangan, melakukan fungsi penting anti infeksi pada sistem imun. Kebanyakan infeksi bakterial sistemik berhubungan dengan kadar CRP yang tinggi. Pengukuran CRP serial menunjukkan korelasi antara konsentrasi CRP serum dengan derajat keparahan penyakit dan responsnya terhadap terapi. Hadirnya CRP serum yang meningkat mengindikasikan adanya infeksi yang tidak terkontrol atau proses patologik yang tidak terselesaikan. Berbagai tipe keganasan, terutama yang ekstensif dan bermetastasis, akan merangsang respons fase akut. Umumnya pada penderita keganasan sistem imunnya tertekan dan cenderung terkena infeksi sekunder yang menghasilkan peningkatan protein fase akut, khususnya CRP. 5

Pemeriksaan albumin serum merupakan metode sederhana dalam memperkirakan fungsi protein dalam tubuh. Malnutrisi dan peradangan akan menekan sintesis albumin. Albumin serum secara umum digunakan untuk menilai status nutrisi, derajat keparahan penyakit, perkembangan penyakit, dan prognosisnya. Penurunan kadar albumin serum (albuminemia) dapat ditemukan di awal stadium keganasan namun seiring perkembangan penyakit, kadar albumin akan turun bermakna dan menjadi indikator untuk prognosis suatu keganasan. ${ }^{6}$

Kedua pemeriksaan CRP dan albumin serum telah diteliti dan dikombinasikan menjadi suatu penilaian objektif penderita keganasan yakni skor prognostik Glasgow (Glasgow Prognostic Score). ${ }^{6}$ Beberapa penelitian melakukan pengukuran petanda peradangan dan kadar albumin serum dalam mencari kaitan prognostik independen pada berbagai keganasan lanjut. Faktor-faktor tersebut ialah respons inflamasi sistemik dengan cara mengukur perubahan konsentrasi protein fase akut, seperti peningkatan konsentrasi CRP sirkulasi serta rendahnya konsentrasi albumin. ${ }^{7}$

Beberapa penelitian telah melaporkan hasil prognosis penderita keganasan baik menggunakan CRP maupun albumin serum sebagai prediktor. Pada penelitian ini, secara terpisah digunakan ke dua prediktor untuk menganalisis perubahan yang terjadi sebelum dan setelah terapi pada pasien kanker payudara stadium lanjut

\section{METODE PENELITIAN}

Penelitian ini bertujuan untuk menilai adanya pengaruh kadar CRP dan albumin serum pada pasien kanker payudara stadium lanjut setelah terapi. Jenis penelitian ialah intervensional analitik dengan desain potong lintang Penelitian dilakukan di RSUP Prof. Dr. R. D. Kandou Manado dengan subjek penelitian ialah semua 
pasien kanker payudara berjenis kelamin perempuan pada periode Mei 2018 s/d Agustus 2018.

Seluruh data penelitian dicatat pada formulir penelitian untuk pengelompokan, penyuntingan, dan pengkodean kenudian data diolah dengan menggunakan program SPSS versi 22.0.

\section{HASIL PENELITIAN}

Selama masa penelitian Mei 2018 sampai Agustus 2018, terdapat 43 pasien yang memenuhi kriteria inklusi dan eksklusi. Usia termuda 34 tahun dan usia tertua 70 tahun dengan rerata usia 52,16 tahun (SD $\pm 10,002$ tahun). Jumlah pasien dengan stadium IIIC sebanyak 11 orang $(25,6 \%)$; stadium IIIA sebanyak 5 orang $(11,6 \%)$; stadium IV sebanyak 2 orang $(4,7 \%)$ (Tabel 1). Terapi yang paling sering diberikan ialah kombinasi $\mathrm{K}+\mathrm{O}$ (kemoterapi dan operasi) sebanyak 40 orang (93\%); terapi $\mathrm{K}$ saja, sebanyak 2 orang $(4,7 \%)$; dan terapi $\mathrm{O}$ saja sebanyak 1 orang $(2,3 \%)$ (Tabel 2).

Sebelum pemberian terapi pada pasien baik berupa kemoterapi (K) dan atau operasi (O), didapatkan kadar CRP serum tertinggi $131 \mathrm{mg} / \mathrm{L}$, dengan kadar teren-dah $2 \mathrm{mg} / \mathrm{L}$ dan rerata 17,05 mg/L (SD $\pm 22,709$ $\mathrm{mg} / \mathrm{dL}$ ). Setelah dilakukan terapi didapatkan kadar CRP serum tertinggi $16 \mathrm{mg} / \mathrm{L}$, kadar terendah $0 \mathrm{mg} / \mathrm{L}$ dan rerata 6,40 $\mathrm{mg} / \mathrm{L}(\mathrm{SD} \pm 3,479 \mathrm{mg} / \mathrm{L})$ (Tabel 3). Karena jumlah subyek penelitian $(n)=43(>30)$, maka tidak dilakukan uji kenormalan data. Untuk uji perbedaan data CRP serum sebelum dan sesudah tindakan digunakan uji $\mathrm{t}$ berpasangan yang menda-patkan $\mathrm{t}=3,269$ dengan $P=0,001$. Hasil uji $\mathrm{t}$ menyatakan terdapat perbedaan yang sangat bermakna antara kadar CRP serum sebelum dan sesudah tindakan. Jadi, pada pasien kanker payudara pasca tindakan terjadi penurunan kadar CRP serum secara sangat bermakna dari rerata $17,05 \mathrm{mg} / \mathrm{L}$ menjadi rerata $6,40 \mathrm{mg} / \mathrm{L}$ (Gambar 1).

Tabel 1. Jumlah dan frekuensi stadium kanker payudara

\begin{tabular}{ccc}
\hline Stadium & Frekuensi & Persentase \\
\hline IIIA & 5 & 11,6 \\
IIIB & 25 & 58,1 \\
IIIC & 11 & 25,6 \\
IV & 2 & 4,7 \\
Total & 43 & 100,0 \\
\hline
\end{tabular}

Tabel 2. Jumlah dan frekuensi terapi yang diberikan pada pasien

\begin{tabular}{ccc}
\hline Terapi & Frekuensi & Persentase \\
\hline $\mathrm{K}$ & 2 & 4,7 \\
$\mathrm{~K}+\mathrm{O}$ & 40 & 93,0 \\
$\mathrm{O}$ & 1 & 2,3 \\
Total & 43 & 100,0 \\
\hline
\end{tabular}

Tabel 3. Kadar CRP serum (mg/dL) sebelum dan sesudah terapi

\begin{tabular}{lccc}
\hline & $\begin{array}{c}\text { Sebelum } \\
\text { terapi }\end{array}$ & $\begin{array}{c}\text { Kadar CRP }(\mathbf{m g} / \mathbf{L}) \\
\text { Sesudah } \\
\text { terapi }\end{array}$ & $\begin{array}{c}\text { Perubahan } \\
\text { kadar }\end{array}$ \\
\hline $\mathrm{N}$ & 43 & 43 & 43 \\
Minimum & 2 & 0 & -2.00 \\
Maksimum & 131 & 16 & 123,00 \\
Median & 12,00 & 6,00 & 5,000 \\
Mean & 17,05 & 6,40 & 10,6512 \\
Std. Deviation & 22,709 & 3,479 & 21,36294 \\
\hline
\end{tabular}

Pada pasien kanker payudara sebelum dilakukan terapi didapatkan kadar albumin serum tertinggi $4,20 \mathrm{mg} / \mathrm{L}$, dengan kadar terendah 3,0 $\mathrm{mg} / \mathrm{L}$ dan rerata $3,5863 \mathrm{~g} / \mathrm{dL}$ $(\mathrm{SD} \pm 0,39277 \mathrm{mg} / \mathrm{L})$. Setelah dilakukan terapi didapatkan kadar albumin terendah 
3,00 $\mathrm{mg} / \mathrm{L}$ dengan kadar albumin tertinggi $4,79 \mathrm{mg} / \mathrm{L}$ dan rerata $3,7556 \mathrm{mg} / \mathrm{L}$ ( $\mathrm{SD} \pm 0,38334 \mathrm{mg} / \mathrm{L}$ ) (Tabel 4). Perbedaan kadar albumin serum sebelum dan sesudah terapi diuji dengan uji t berpasangan yang mendapatkan $\mathrm{t}=-2,896$ dengan $P=0,003$. Hasil uji $t$ ini menyatakan terdapat perbedaan yang sangat bermakna antara kadar albumin sebelum dan sesudah terapi $(P<0,001)$. Jadi, pada pasien kanker payudara terjadi peningkatan kadar albumin serum secara sangat bermakna dari rerata $3,59 \mathrm{mg} / \mathrm{L}$ menjadi rerata $3,76 \mathrm{mg} / \mathrm{L}$ (Gambar 2).

Tabel 4. Kadar albumin serum (mg/L) sebelum dan sesudah terapi

\begin{tabular}{lccc}
\hline & $\begin{array}{c}\text { Sebelum } \\
\text { terapi }\end{array}$ & $\begin{array}{c}\text { Kadar albumin }(\mathbf{m g} / \mathbf{L}) \\
\text { Sesudah } \\
\text { terapi }\end{array}$ & $\begin{array}{c}\text { Perubahan } \\
\text { kadar }\end{array}$ \\
\hline $\mathrm{N}$ & 43 & 43 & 43 \\
Minimum & 3,00 & 3,00 & $-1,05$ \\
Maksimum & 4,20 & 4,79 & 0,86 \\
Median & 3,5300 & 3,6800 & $-0,1900$ \\
Mean & 3,5863 & 3,7556 & $-0,1693$ \\
Std. Deviation & 0,39277 & 0,47331 & 0,38334 \\
\hline
\end{tabular}

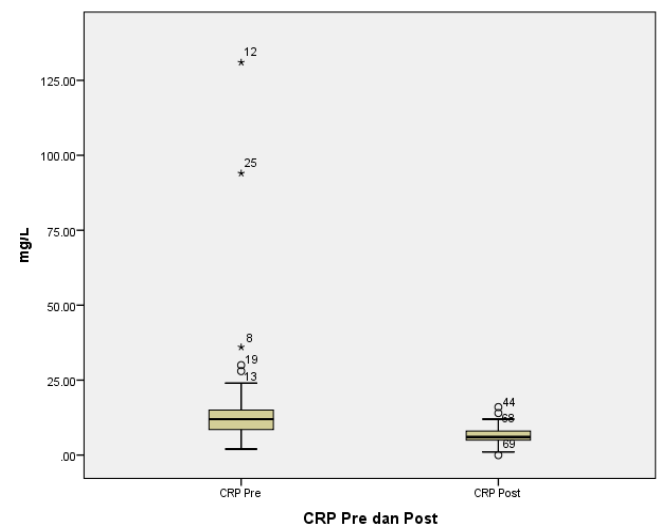

Gambar 1. Grafik Box-Whisker sebaran data kadar CRP serum sebelum dan sesudah terapi

\section{BAHASAN}

Selama masa penelitian sejak bulan Mei 2018 sampai Agustus 2018 didapatkan 43 pasien kanker payudara yang dirawat di Bagian Bedah RSUP Prof. Dr. R. D. Kandou Manado dan memenuhi kriteria inklusi dan eksklusi. Usia termuda ialah 34 tahun dan usia tertua 70 tahun dengan rerata usia 52,16 tahun ( $\mathrm{SD} \pm 10,002$ tahun). Stadium yang paling banyak ialah stadium IIIB $(58,1 \%)$, diikuti stadium IIIC $(25,6 \%)$, stadium IIIA $(11,6 \%)$, dan stadium IV $(4,7 \%)$. Terapi yang paling sering diberikan berupa kombinasi kemoterapi dan operasi

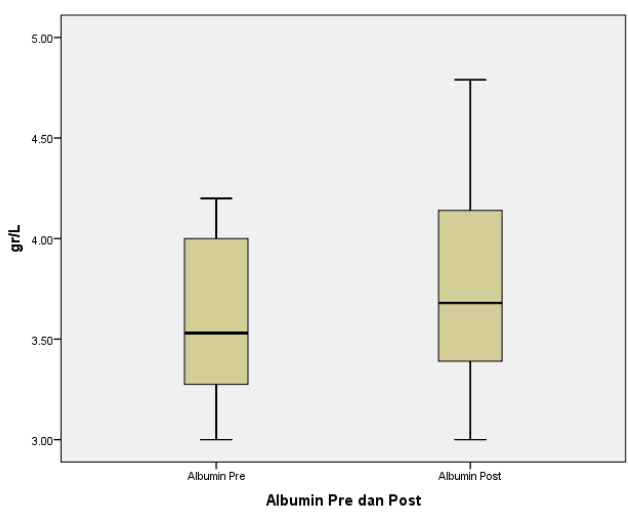

Gambar 2. Grafik Box-Whisker sebaran data kadar albumin serum sebelum dan sesudah terapi

sebanyak 40 pasien (93\%), kemoterapi sebanyak 2 pasien $(4,7 \%)$, dan operasi sebanyak 1 pasien $(2,3 \%)$.

Perkembangan tumor merupakan suatu proses kompleks yang berhubungan dengan interaksi antara tumor dan sel inang. Organisme memberikan respons spesifik dan non-spesifik terhadap sel tumor. ${ }^{8}$ Respons non-spesifik meliputi pengeluaran sitokin, faktor pertumbuhan, dan protein fase akut dari hati. Segala bentuk kerusakan jaringan yang signifikan memicu fase respons akut pada berbagai tipe keganasan, terutama saat terjadi perkembangan eksten- 
sif dan menyebar. CRP merupakan protein pertama yang ditemukan sebagai reaktan fase akut. ${ }^{9}$ CRP adalah protein fase akut klasik yang menggambarkan percepatan konsentrasinya dalam plasma terhadap respons inflamasi akut, infeksi, dan kerusakan jaringan. Dibandingkan protein fase akut lainnya, CRP memiliki angka perubahan tertinggi saat terjadi inflamasi akut yaitu meningkat 8-12 jam setelah inflamasi dengan waktu paruh 19 jam. $^{10}$ Sintesis CRP diatur oleh sitokin IL-1, IL-6, dan TNF. Peningkatan kadar CRP merupakan indikator respons inflamasi non-spesifik sekunder terhadap nekrosis tumor atau kerusakan jaringan lokal. ${ }^{11}$

Terdapat dua hipotesis mengenai hubungan antara kadar CRP serum dan keganasan. Pertama, peningkatan CRP serum merupakan akibat dari adanya keganasan itu sendiri. Kedua, inflamasi kronik dan CRP yang tinggi menjadi penyebab utama terjadinya karsinogenesis. Pada pandangan terakhir ini, kerusakan oksidatif akibat inflamasi dapat menginisiasi karsinogenesis dengan menginaktifasi gen penekan tumor atau modifikasi pada protein perbaikan DNA pasca translasi atau kontrol apoptotik. ${ }^{12}$ Sebagai tambahan, sitokin inflamasi memberi sinyal melalui enzim intrasel dan faktor-faktor transkripsi yang hasil akhirnya menghambat apoptosis dan memromosikan pertumbuhan dan perkembangan sel kanker. Lebih jauh lagi, aktivasi dari jalur inflamasi memfasilitasi perkembangan tumor dengan memromosikan motilitas sel, permeabilitas pembuluh darah, dan angiogenesis. $^{13}$

Secara mekanisme, terdapat tiga komponen yang menjelaskan hubungan antara peningkatan kadar CRP dan prognosis keganasan payudara. Pertama, sifat sel tumor: kadar CRP plasma merefleksikan agresifitas dari tumor, oleh karena itu, kadar CRP plasma memberikan informasi prognostik karakteristik tumor, seperti stadium dan gradasi tumor. ${ }^{14}$ Penelitian akhirakhir ini menyatakan bahwa peningkatan kadar CRP berhubungan dengan ukuran besarnya tumor, adanya metastasis jauh, dan gradasi tumor. Kedua, inflamasi seki- tar: kadar CRP plasma mengekspresikan keadaan lingkungan mikro tumor payudara. Jalur inflamasi berperan penting di tiap tingkatan tumorigenesis, meliputi inisiasi dan promosi tumor, transformasi keganasan, invasi tumor, dan metastasis. ${ }^{15}$ Tumor padat memicu respons inflamasi yang menghasilkan formasi lingkungan mikro yang pro-tumorigenik dan pro-angiogenik sekitar tumor. Sel-sel radang dan imunitas pada lingkungan mikro tumor berinteraksi dengan sel-sel keganasan, hasil akhirnya ialah stimulasi pertumbuhan tumor, invasi, dan metastasis. Ketiga, sifat inang: kadar CRP plasma menggambarkan keadaan umum penderita saat didiagnosis menderita keganasan payudara. Pada penelitian terbaru, diperoleh peningkatan kadar CRP berhubungan dengan merokok dan indeks massa tubuh penderita yang besar. ${ }^{16}$

Ljunberg et al $^{17}$ menyatakan peningkatan kadar IL-6 dan CRP dapat menjadi tanda penyakit metastasis. Pada penelitian oleh Bien et al, ${ }^{18}$ ditunjukkan bahwa CRP, LED, dan LDH menjadi tanda diagnostik yang penting dan pemantauan perkembangan keganasan pada anak.

Pada penelitian ini sebelum dilakukan terapi didapatkan kadar CRP tertinggi $131,00 \mathrm{mg} / \mathrm{dL}$ dan kadar terendah 2,00 $\mathrm{mg} / \mathrm{L}$ dengan rerata $12,00 \mathrm{mg} / \mathrm{L} \quad(\mathrm{SD} \pm$ $22,709 \mathrm{mg} / \mathrm{L})$. Setelah dilakukan terapi didapatkan kadar CRP tertinggi 16,00 $\mathrm{mg} / \mathrm{L}$, kadar terendah $0,00 \mathrm{mg} / \mathrm{L}$, dengan rerata $6,40 \mathrm{mg} / \mathrm{L}(\mathrm{SD} \pm 3,479 \mathrm{mg} / \mathrm{L})$. Kadar CRP menurun pada penderita kanker payudara setelah dilakukan tindakan $(P<0,001)$. Kadar CRP ini cukup bermakna menurun dibandingkan nilai parameter lainnya. Perbedaan CRP sebelum dan setelah dilakukan terapi diuji dengan uji $\mathrm{t}$ berpasangan mendapatkan $\mathrm{t}=3,269$ dan $P=0,001$, yang menunjukkan bahwa pada pasien kanker payudara pasca terapi terjadi penurunan kadar CRP serum secara sangat bermakna dari rerata $17,05 \mathrm{mg} / \mathrm{L}$ menjadi rerata $6,40 \mathrm{mg} / \mathrm{L}$. Hasil ini sesuai dengan acuan pustaka yang menyimpulkan bahwa pasca terapi, respons inflamasi menurun yang pada penelitian ini dibuktikan dengan penurunan kadar CRP secara bermakna. ${ }^{10-14}$ 
Berkaitan dengan albumin, terdapat sekumpulan data acuan pustaka medik yang menunjukkan hubungan antara tingkat albumin dengan mortalitas suatu keganasan. Pada penderita dengan keganasan lanjut atau stadium terminal, didapatkan kadar albumin serum yang rendah. Goransson et $\mathrm{al}^{19}$ melaporkan bahwa kadar albumin serum rendah (albumin $<3,7 \mathrm{~g} / \mathrm{dL}$ ) seringkali terjadi pada penderita dengan keganasan yang tidak dapat dioperasi. Pada penelitian Laursen et $\mathrm{al}^{20}$ didapatkan tingkat albumin yang tinggi menghambat proliferasi sel tumor payudara yang responsif terhadap estrogen dengan modulasi aktivitas autokrin faktor regulasi pertumbuhan. Selain itu, Soreide et $\mathrm{al}^{21}$ melaporkan korelasi antara serum albumin dengan kejadian angka kekambuhan kanker payudara stadium I dan II, serta menyatakan bahwa albumin pada sitosol sel kanker payudara menghambat pertumbuhan tumor.

Christopher et $\mathrm{al}^{22}$ menyatakan bahwa kadar albumin serum yang rendah berhubungan dengan perubahan metabolik yang diakibatkan oleh stres, penyakit, insufisiensi hati, dan pengurangan massa protein organ dalam atau penurunan kemampuan sintesis albumin. Harus dipertimbangkan dalam penentuan kecukupan keadaan nutrisi serta kebutuhan penunjang nutrisi karena penunjang nutrisi yang agresif pada penderita keganasan ternyata efektif untuk memelihara status nutrisi dalam menerima seluruh terapi sehingga memberikan efek yang positif. $^{22}$

Pada penelitian ini sebelum dilakukan terapi didapatkan kadar albumin serum tertinggi 4,20 $\mathrm{mg} / \mathrm{L}$, terendah $3,0 \mathrm{mg} / \mathrm{L}$, dan rerata 3,5863 $\mathrm{mg} / \mathrm{L}(\mathrm{SD} \pm 0,39277 \mathrm{mg} / \mathrm{L})$. Setelah dilakukan terapi didapatkan kadar albumin serum terendah 3,00 $\mathrm{mg} / \mathrm{L}$, tertinggi $4,79 \mathrm{mg} / \mathrm{L}$, dan rerata 3,7556 $\mathrm{mg} / \mathrm{L} \quad(\mathrm{SD} \pm 0,38334 \mathrm{mg} / \mathrm{L})$. Perbedaan kadar albumin serum sebelum dan setelah terapi diuji dengan uji $\mathrm{t}$ berpasangan mendapatkan nilai $\mathrm{t}=-2,896$ dan $P=0,003$ yang menunjukkan bahwa pada pasien kanker payudara pasca terapi terjadi peningkatan kadar albumin serum secara sangat bermakna dari rerata $3,59 \mathrm{mg} / \mathrm{L}$ menjadi rerata 3,76 mg/L. Hasil ini sesuai dengan acuan pustaka yang menyimpulkan bahwa pasca terapi kadar albumin serum meningkat yang pada penelitian ini dibuktikan dengan peningkatan kadar albumin serum secara bermakna.

\section{SIMPULAN}

Berdasarkan hasil penelitian ini dapat disimpulkan bahwa terapi yang diberikan baik kemoterapi dan/atau operasi pada pasien kanker payudara stadium lanjut menurunkan kadar CRP serum dan meningkatkan kadar albumin serum.

\section{DAFTAR PUSTAKA}

1. Siegel R, Naishadham D, Jemal A. Cancer statistics, 2017. CA Cancer J Clin. 2017;62:10-29.

2. Tjindarbumi D, Mangunkusumo R. Cancer in Indonesia: present and future. Jpn J Clin Oncol. 2002;32(Suppl. 1):S17-S21

3. Mantovani A, Marchesi F, Porta C, Sisca A, Allavena P. Inflammation and cancer: breast cancer as a prototype. Breast. 2007;16(Suppl 2):S27-S33.

4. Coussens LM, Werb Z. Inflammation and cancer. Nature. 2002;420:860-7.

5. Peisajovich A, Marnell L, Mold C, Du Clos TW. C-reactive protein in the interface between innate immunity and inflammation. Expert Rev Clin Immunol. 2008;4(3):379-90.

6. Al Murri AM, Bartlett JM, Canney PA, Doughty JC, Wilson C, McMillan DC. Evaluation of an inflammationbased prognostic score (GPS) in patients with metastatic breast cancer. Br J Cancer. 2006;94:227-30.

7. Gabay C, Kushner I. Acute phase proteins and other systemic responses to inflammation. N Engl J Med. 1999; 340(6):448-54.

8. Wieland A, Kerbl R, Berghold A, Schwinger W, Mann G, Urban C. Creactive protein as tumor marker in pediatric and adolescent patients with Hodgkin disease. Med Pediatr Oncol. 2003;41(1):21-5.

9. Kallio R, Bloigu A, Surcel HM, Syrjala H. C-reactive protein and erythrocyte sedimentation rate in differrential diagnosis between infections and neoplastic fever in patients with solid 
tumos and lymphomas. Support Care cancer. 2001;9(2):124-8.

10. Nozoe T, Matsumata $T$, Kitamura $M$, Sugimachi K. Significance of preoperative elevation serum C-reactive protein as an indicator for prognosis in colorectal cancer. Am J Surg. 1998; 176(4):335-8.

11. Koenig W, Sund M, Frochlich M, Fisher H, Lowel H, Doring A, et al. Creactive protein, a sensitive marker of inflammation, predicts future risk of coronary heart disease in initially healthy middle aged men. Circulation. 1999;99(2):237-42.

12. Heikkila K, Ebrahim S, Lowlor DA. A systematic review of the association between circulating concentration of $\mathrm{C}$ reactive protein and cancer. $\mathrm{J}$ Epidemiol Community Health. 2007; 61:824-33.

13. Gauldie J, Richards C, Harnish D, Lansdrop P, Baumann H. Interferon beta2/B-cell stimulatory factor type 2 shares identity with monocyte-derived hepatocyte-stimulating factor and regulates the major acute phase protein response in liver cells. Proc Natl Acad Sci USA. 1987;84:7251-5.

14. Colotta F, Allavena P, Sica A, Garlanda C, Mantovani A. Cancer-related inflamemation, the seventh hallmark of cancer: links to genetic instability. Carcinogenesis. 2009;30:1073-81.

15. Coussens LM, Werb Z. Inflammation and cancer. Nature. 2002;420:860-67.

16. Gnvennikov SI, Greten FR, Karin M.
Immunity, inflammation, and cancer. Cell. 2010;140:883-99.

17. Ljunberg B, Grankvist K, Rasmuson T. Serum interleukin-6 in relation to acute-phase reactants and survival in patients with renal cell carcinoma. Eur J Cancer. 1997;33(11):1794-8.

18. Bien E, Balcerska A. Clinical significance oe erythrocyte sedimentation rate, Creactive protein and serum lactate dehydrogenase levels in diagnosis, prognosis and treatment monitoring of children suffering from cancer. Med Wieku Rozwoj. 2004;89(4):396-9.

19. Goransson J, Jonsson S, Lasson A. Preoperative plasma levels of C-reactive protein, albumin and various plasma protease inhibitors for the pre-operative assessment of operability and recurrence in cancer surgery. Eur J Surg Oncol. 1996;22:607-17.

20. Laursen I, Briand P, Lykkesfeldt AE. Serum albumin as modulator on growth of the human breast cancer cell line, MCF-7. Anticancer Res. 1990;10:34352.

21. Soreide JA, Lea OA, Kvinnsland S. Cytosol albumin content in operable breast cancer. Correlation to steroid hormone receptors, other prognostic factors and prognosis. Acta Oncol. 1991;30:797802.

22. Christopher S, Glare $P$, Downing $M$, Stone P, Maltoni M, Vigano A. Predicting survival in patients with advanced disease. Eur J Cancer. 2008;44:114656. 